\title{
WORKPLACE STRESSORS AND MOTIVATION OF EMPLOYEES IN EDUCATIONAL INSTITUTIONS
}

\author{
Milica Milojevic ${ }^{1}$, Gordana Colovic ${ }^{2}$, Sladjana Milojevic ${ }^{3}$, Mina Paunovic ${ }^{2}$ \\ ${ }^{1}$ Ministry without Portfolio, Cabinet of Demography and Population Policy, Belgrade \\ ${ }^{2}$ The College of Textile - Design, Technology and Management, Belgrade \\ ${ }^{3}$ First Kragujevac Grammar School \\ e-mail:gordanacolovic@gmail.com
}

\begin{abstract}
The aim of this work is to analyse the causes which lead to the stress in educational institutions and see what is their connection to the motivation of the employees. The stress is the scheme of emotional and physiological reactions arising as a response to the demands set within or outside the organisation. Using the poll technique, it deals with the causes of stress among the employees in the educational institutions, as well as the level of their motivation. Specific relations between the features of stress and motivation should show the relation between the stress generated by different causes and the motivation of the employees.
\end{abstract}

Keywords: stress at work, motivation at work, educational institutions.

\section{INTRODUCTION}

Following significant changes in the environment resulting from the development of science and technology, education, as well as the overall educational system, succumbed to the reforms. In this way, social changes have influenced its reform, which included changes in the structure, functioning and efficiency of education, the network of educational institutions, educational programs, forms and content, as well as the objectives and methods of education. [1]

Motivation, like no other psychological variables, can not be measured directly. It is concluded from the behavior, size of commitment, perseverance and direction of behavior, or behavior whose results are achieved. It is an indicator of the performance of work, or the accomplishment of personal and organizational goals. On the other hand, if the job requirements are complex and not in accordance with the expectations, abilities, knowledge and skills of people, if they do not fit into the time available and the usual rhythm properly, if the conditions at work are outside the limits of physical and psychological tolerance and moral values without the opportunities for training and advancement, if the job is insecure, socially unrecognized, underpaid, filled with rejection and conflicts among the staff, the result is a destructive and unpleasant experience of the stress at work.

\section{MOTIVATION AND CAUSES OF STRESS OF EMPLOYEES IN EDUCATIONAL INSTITUTIONS}

In modern society characterized by frequent changes educational systems around the world sarch for the ways how to get more appropriate and effective responses to these rapid and complex changes. In order to keep pace with all the changes and modern trends of teaching and education in general there is a necessity for their training in the context of continuous professional development. The importance of a quality teacher is indisputable because it is directly connected to the quality of learning, ie. educational outcomes of students. [2] 


\section{ARTTIE $Y$}

Ipplied Resseirlohes in Technics, Technologies and Bductation

Journal of the Faculty of Technics and Technologies, Trakia University https://sites.google.com/a/trakia-uni.bg/artte/

The new role of students in the teaching process is determined by the degree of implementation of new technologies and the development of new learning methods. Practically speaking, students have more time for asking questions, absorbing knowledge, thinking, using acquired knowledge, researching, synthesizing of the acquired learning and imagination. [3]

Very little is known about the motivation of teachers, nobody deals with it or pays attention to it, and it is closely related to the efficiency of schools. Greater motivation means greater efficiency too, and greater efficiency leads back to greater motivation in work and vice versa. This is achieved provided that the motivational elements are implemented appropriately and in accordance with the needs of the school. [4] The motivation of teachers is an important determinant of student motivation. The motivation of teachers is essential for the course of teaching and transferring knowledge to students. Unmotivated teachers can reduce the motivation of students, whereas motivated teachers create a positive and friendly atmosphere in the classroom. There is a chain link between the style of leadership of school principals, school climate, the quality of teachers' motivation, style of teachers in the management of processes in the classroom, the quality of students' motivation and outcomes to be achieved in their school work and learning.

Various studies indicate that the motivation of teachers is influenced by attending professional meetings and other forms of training where they learn new skills and competences, where there is an exchange of information with colleagues, helping each other with their pieces of advice and practical examples. Every professional training financed by the employer is seen by a large number of teachers as a kind of reward and extra motivation. The diversity of work and the work with pupils or students are the main motivation for most teachers and employees in educational institutions. The overload of duties, the increased pace of modern life, dissatisfaction at work and personal difficulties seem stressful to students and teachers who face difficulties in finding solutions in adapting to these situations and look for new pedagogical solutions. [5] Therefore, the employees are less motivated for work and it makes it even harder for them to motivate pupils or students.

As a result of inadequate preparation for new roles and responsibilities imposed by the dynamic changes in education the stress can occur among teachers. The analysis of the main components of the sources of stress demonstrated that they could be described, for the most part, within four orthogonal factors: "bad student behavior," "poor working conditions", "lack of time" and "poor school ethos." [6]

The way in which the teacher faces with stress depends on his personal characteristics and capacities, with a distinct importance being his interpretation of a given situation. Many studies on stress and exhaustion at work indicate that younger teachers experienced larger emotional exhaustion in relation to the older ones, which the authors explained as their unrealistic expectations of the teaching profession that have been left unfulfilled, becoming a source of stress and frustration. [7] According to Goddard [8] the teachers beginners experience less stress because they are considered more capable than the older ones in the use of modern teaching methods, and some authors [9] showed that they are more satisfied with their work, which also can reduce the level of stress.

\section{EXPERIMENTS AND RESULTS}

The data needed for the analysis of stress and motivation at work were collected through a survey, on two samples:

- A sample of employees in college.

- A sample of employees in high school. 


\section{ARTITE

The research sample is 52 respondents.

To answer these questions, it was necessary to find out in the survey certain data on employees in these institutions: age, education, work experience and sex. Of the total number of employees in both educational institutions 55 are females (74\% and $75 \%)$ and 3 respondents are male (26\% and $25 \%)$.

Years of age are classified into 5 categories. In the first category are the employed up to 30 years (16\%), 30 to 40 years make $46 \%$ of respondents. Most respondents are in the category from 41 to 50 years (65\%).

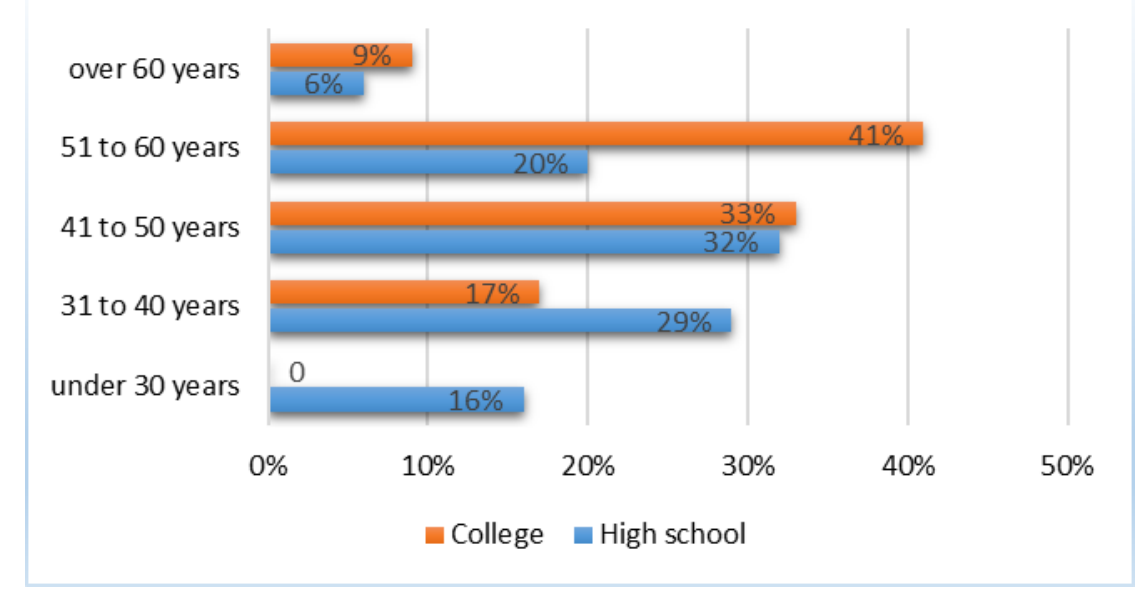

Figure 1.

Distribution of respondents according to their age

Most respondents in both educational institutions are the employees whose work experience is from 21 to 30 years (35\% and $41 \%$ ), wheras the least respondents have more than 30 years of work experience $(10 \%$ and $9 \%)$.

General conditions at work are assessed by the employees in both schools as "mostly good" - 52\% in high school and $75 \%$ in college, Table 1.

Table 1. General conditions at work

\begin{tabular}{|l|c|c|c|c|c|}
\hline $\begin{array}{l}\text { General } \\
\text { conditions } \\
\text { at work }\end{array}$ & $\begin{array}{c}\text { Extremely } \\
\text { poor }\end{array}$ & Very bad & Average & $\begin{array}{c}\text { Mostly } \\
\text { good }\end{array}$ & Excellent \\
\hline $\begin{array}{l}\text { high } \\
\text { school }\end{array}$ & - & $13 \%$ & $32 \%$ & $52 \%$ & $3 \%$ \\
\hline college & - & - & $25 \%$ & $75 \%$ & - \\
\hline
\end{tabular}

IRTIIE Vol. 4, No. 3, 2016 ISSN 1314-8788 (print), ISSN 1314-8796 (online), doi: 10.15547/artte.2016.03.009 


\section{IRTITE}

Ipplied Researrches in Technics, Technologies ind Educiation Journal of the Faculty of Technics and Technologies, Trakia University https://sites.google.com/a/trakia-uni.bg/artte/

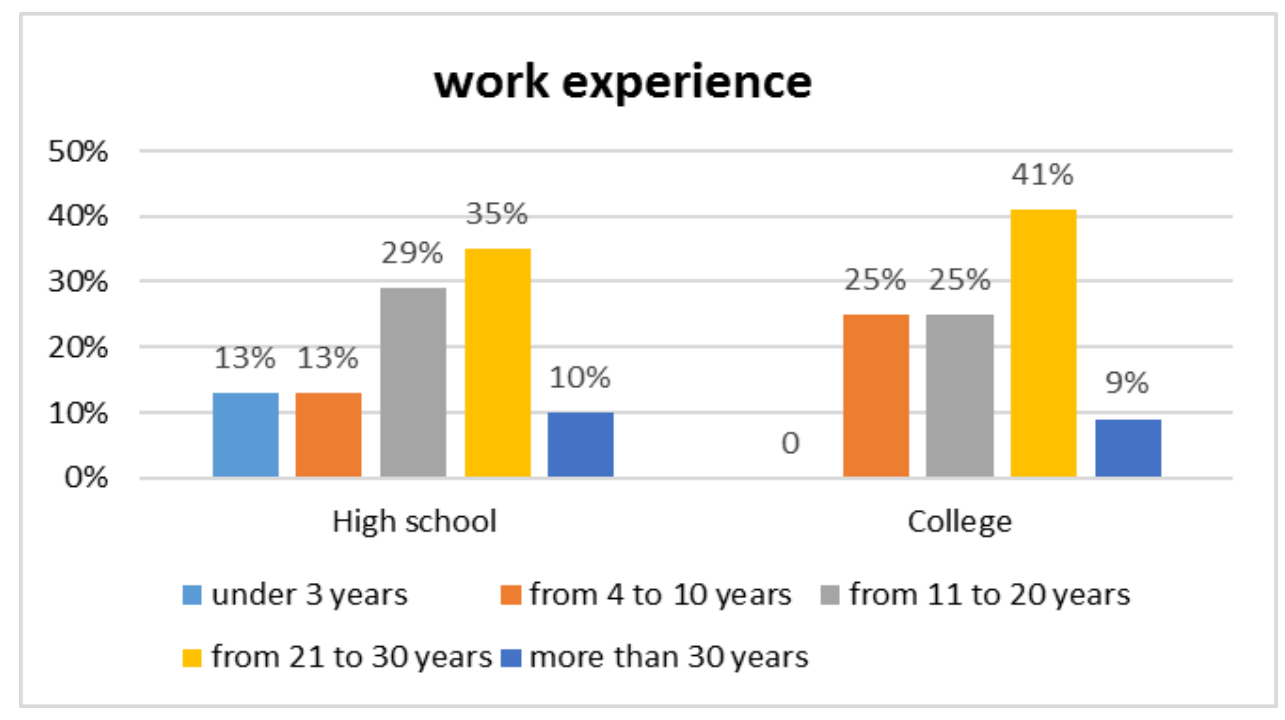

Figure 2. Working experience of the respondents

Physical conditions have no particular impact on motivation but they have on job satisfaction, and according to Boris Petz the formula of the company performance related to the motivation and working conditions of employees [10] is:

success $=$ ability $\mathrm{x}$ motivation $\mathrm{x}$ working conditions

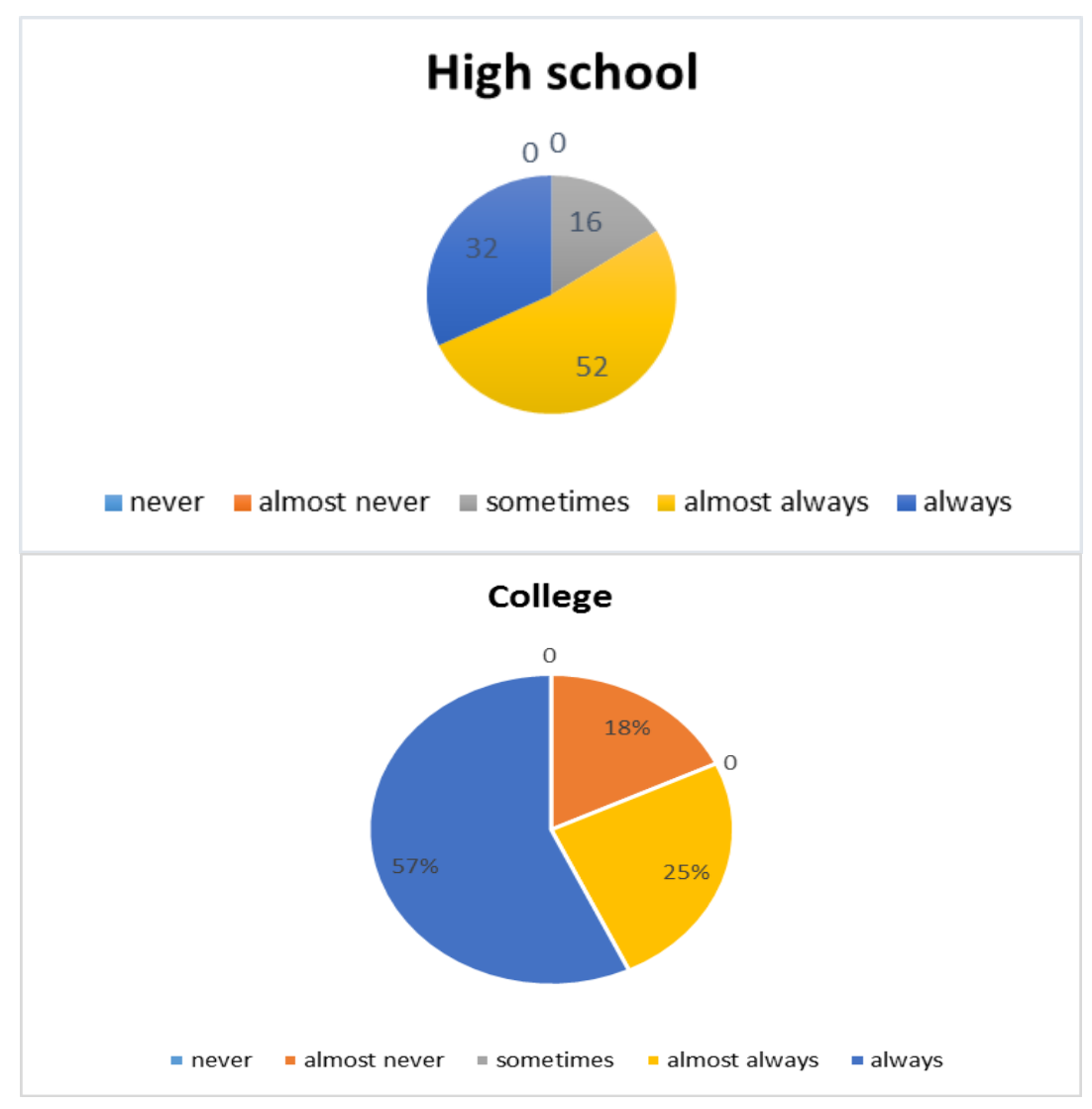

Figure 3. How often do you understand the tasks related to your job?

IRTITE Vol. 4, No. 3, 2016 ISSN 1314-8788 (print), ISSN 1314-8796 (online), doi: 10.15547/artte.2016.03.009 


\section{IRITIE}

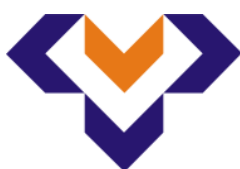

Ipplied Resseirl'hes in Teednicis, Technologies and Eductation

Journal of the Faculty of Technics and Technologies, Trakia University https:///ites.google.com/a/trakia-uni.bg/artte/

Many authors suggest that there is a big problem concerning the tasks and activities of employees in many companies not being clear. Answers to the question "How often do you understand the tasks related to your job?" indicate that there are usually no such problems in educational institutions. The majority of respondents in both schools "always" (52\%, 25\%) and "almost always" (32\%, 57\%) understood their tasks at work, Figure 3.

The question in the survey "How often do you do the tasks that do not belong to you?" is set to indicate either good or bad organization of two institutions, but als the possibility of job dissatisfaction and causes of additional stress for employees. In high school $23 \%$ never do the tasks that do not belong to them, $10 \%$ almost never and $48 \%$ sometimes. In the college $33 \%$ of employees never do the tasks that do not belong to them, $9 \%$ almost always and $33 \%$ of employees still work on the tasks that are not in their job description (Figure 4).

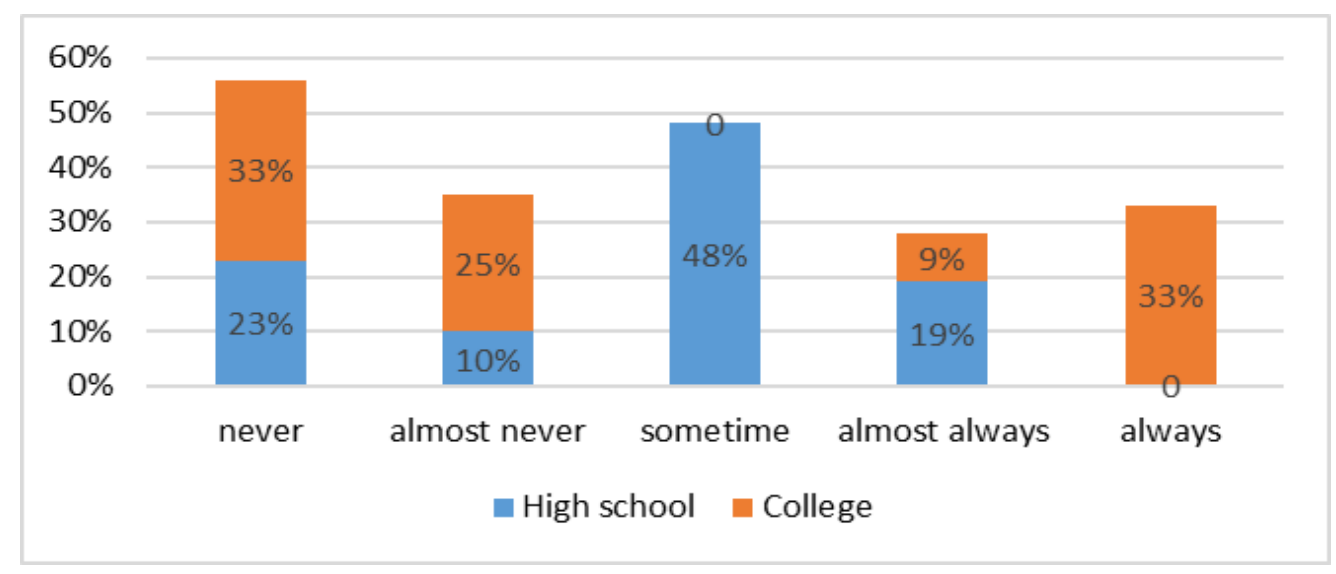

Figure 4. How often do you do the tasks that you do not belong?

Answers to the question "How often do you work overtime?" are shown in Table 2. The obtained answers show that a large percentage of employees in education often work overtime due to the increased workload.

Table 2. How often do you work overtime?

\begin{tabular}{|l|c|c|c|c|c|}
\hline $\begin{array}{l}\text { How often do you } \\
\text { work overtime? }\end{array}$ & Never & $\begin{array}{c}\text { Almost } \\
\text { never }\end{array}$ & Sometime & $\begin{array}{c}\text { Almost } \\
\text { always }\end{array}$ & Always \\
\hline high school & - & $26 \%$ & $61 \%$ & $13 \%$ & - \\
\hline college & $33 \%$ & - & $18 \%$ & - & $49 \%$ \\
\hline
\end{tabular}

There are many methods of motivation (recognition, attention, applause, additional responsibility, certiicates and trophies, interviews with employees, the emphasis on positive aspects of good work done with the support and encouragement, training, affiliations, socializing with employees, sporting events, competitions) that contribute to improving interpersonal relationships and building relationships of employees to the organization. [11] Therefore, the survey asked the question how employers contribute to employees motivation through praise, bonus, promotion and salary increase.

Figure 5 shows that the divided opinions about the impact of praise employer to employees' motivation. The highest percentage of respondents from high schools (52\%), mostly agree that praise affect them, while $33 \%$ of respondents in the college in general do not agree with this view. 


\section{IRTIIE

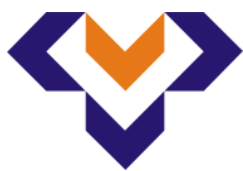

Ipplied Researroches in Technics, Technologies and Bduration

Journal of the Faculty of Technics and Technologies, Trakia University https:///ites.google.com/a/trakia-uni.bg/artte/

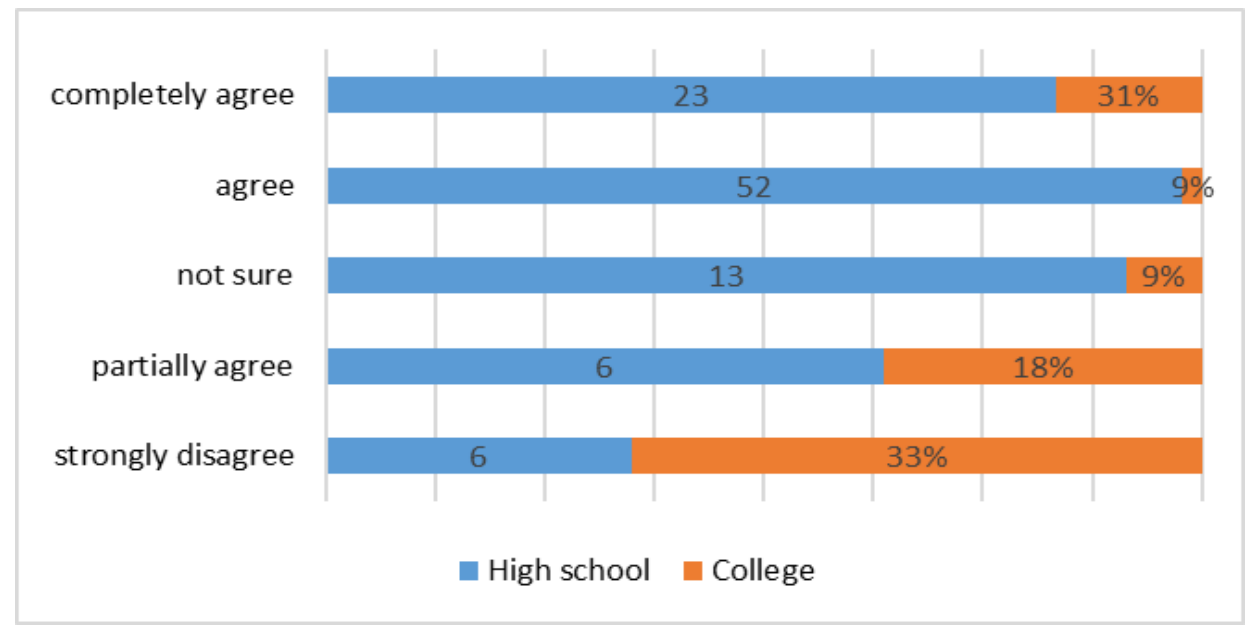

Figure 5. The influence of praise to motivation

The majority of respondents in both schools finds that bonuses do not contribute to their motivation (59\% in high school and 58\% in college), Figure 6. Increasing wages would not affect the motivation of employees in high school (81\%) and $50 \%$ of employees in college, where there are different opinions and $24 \%$ of respondents believe that this would affect their motivation.

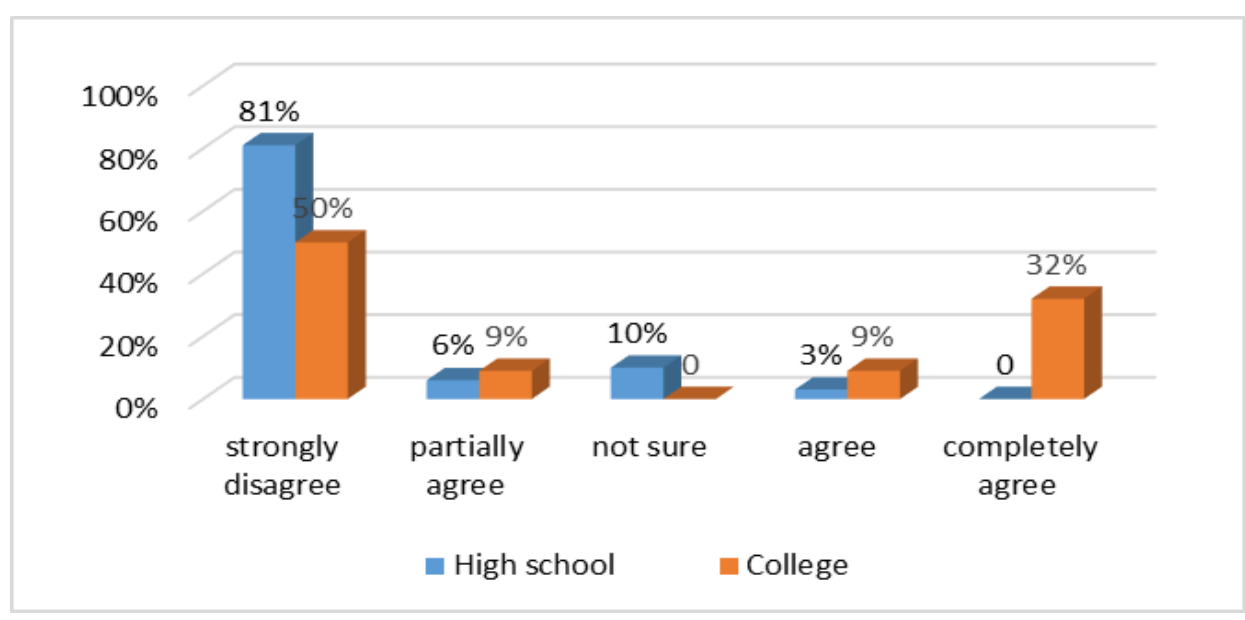

Figure 6. The effect of the increase in wages on motivation

The influence of family, health and social status of employees' motivation and general life satisfaction is very important, too. The motivation of employees in high school is mostly influenced by the health status $(45 \%)$, and the least the financial situation (10\%). Opinions are divided as to how the children of employees affect their motivation because $32 \%$ of respondents believe that they have no influence on their motivation, whereas $26 \%$ think they have a big influence on them. The health status has no influence on their colleagues in college $(82 \%)$, and their motivation is mostly influenced by salaries of other family members (73\%). Similar opinions are divided among the colleagues in high school concerning how much children affect the motivation. $33 \%$ of respondents believe that they have no influence on their motivation, while $31 \%$ think they have a big influence on them. Figures 7 and 8 are show their responses.

IRITIE Vol. 4, No. 3, 2016 ISSN 1314-8788 (print), ISSN 1314-8796 (online), doi: 10.15547/artte.2016.03.009 


\section{IRTIIE}

Ipplied Reserertches in Technics, Technologies and Bduration

Journal of the Faculty of Technics and Technologies, Trakia University https:///ites.google.com/a/trakia-uni.bg/artte/

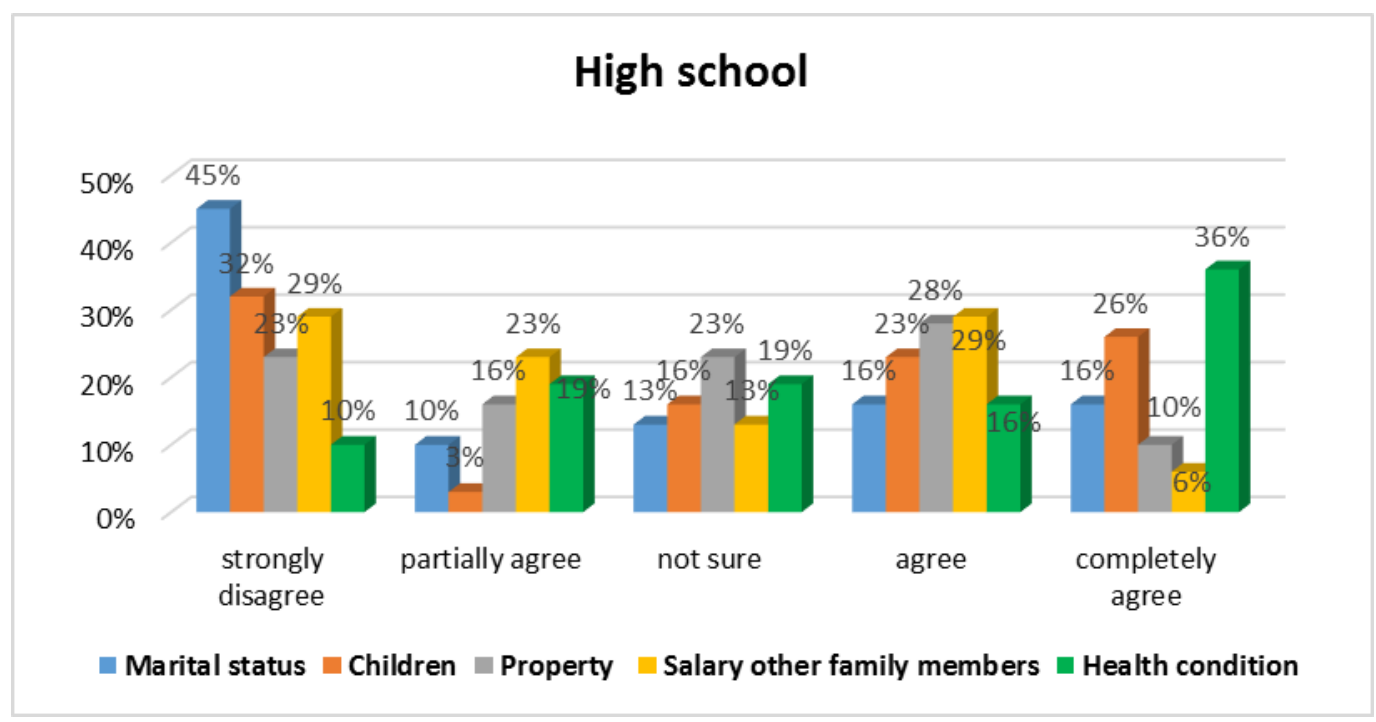

Figure 7. Influence on employees' motivation in high school

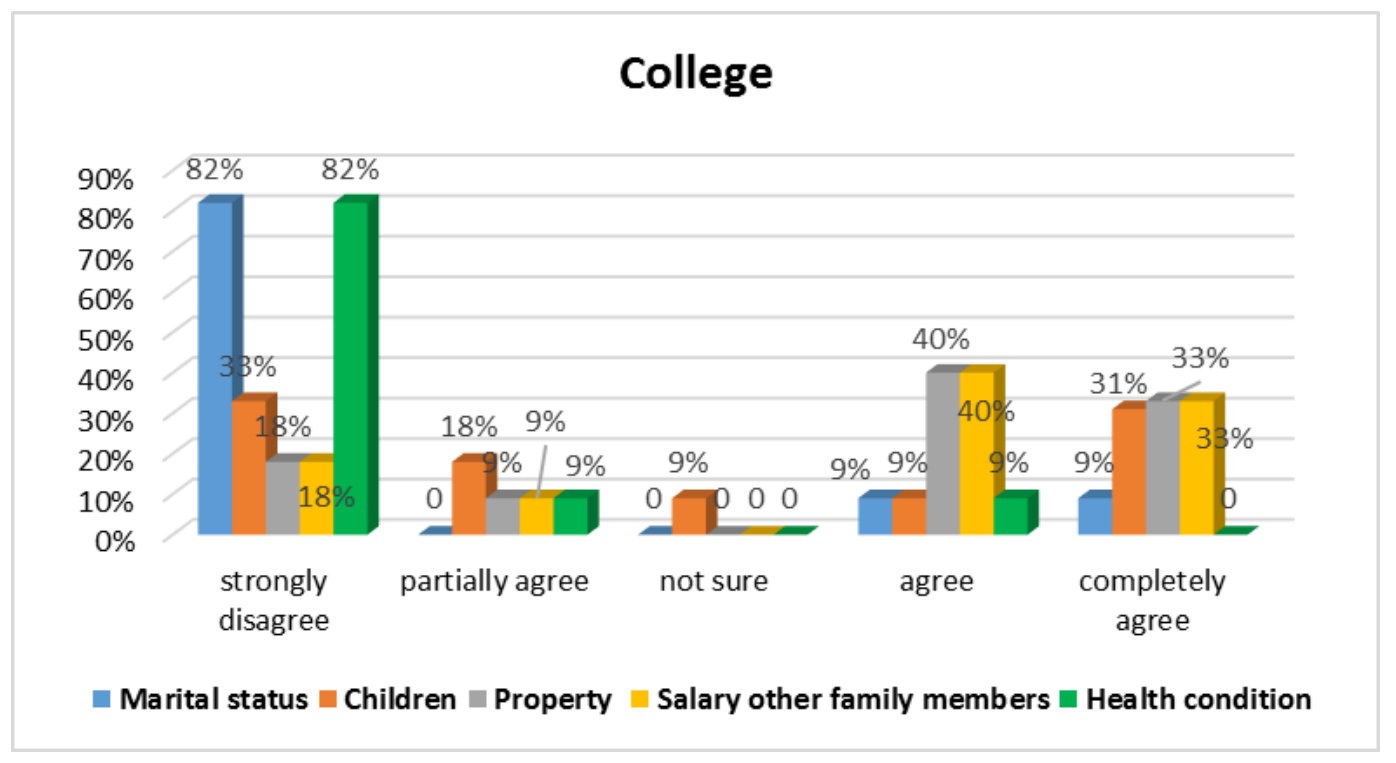

Figure 8. Impacts on the motivation of employees in the college

Social factors which include the degrees of satisfaction and dissatisfaction in the workplace are factors that managers who deal with the internal communication put great emphasis today. [11] The survey includes the issues related to socio-economic factors: interesting work, keeping a job, relationships, status and personal income of respondents.

At work, most respondents are motivated by interesting work, status and having a permanent job among the respondents in both schools, and the smallest number by personal income and interpersonal relations. 


\section{IRTIIE}

Ipplied Researroches in Technics, Technologies and Eduration

Journal of the Faculty of Technics and Technologies, Trakia University https://sites.google.com/a/trakia-uni.bg/artte/

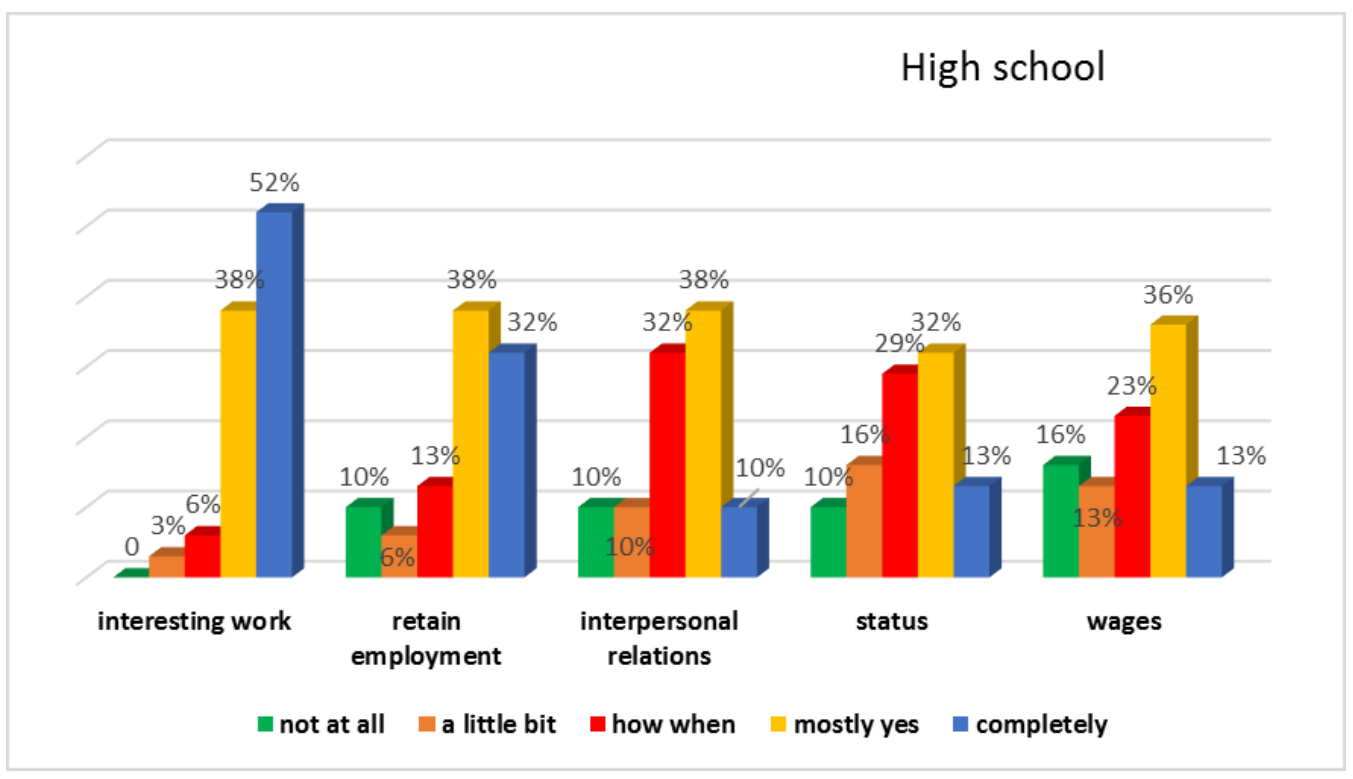

Figure 9. What motivates employees in high school

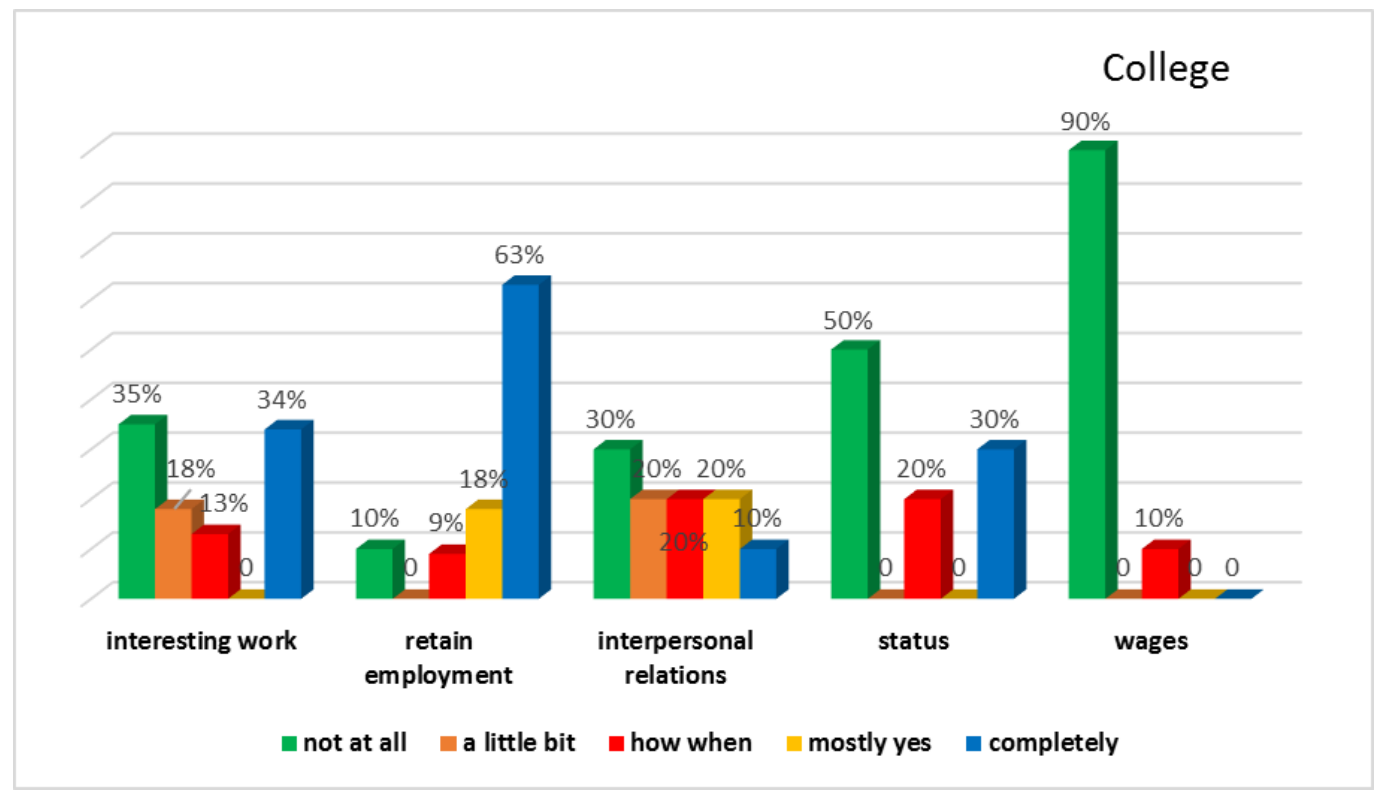

Figure 10. What motivates employees in college

Poor interpersonal relationships interfere with their work mostly of $19 \%$ of employees and sometimes $38 \%$ of employees of high school. At the college bad relationships interfere with the work mostly $40 \%$ and sometimes $40 \%$.

The unfavorable conditions of work environment are noise, vibration, temperature, humidity, lighting, etc.. These factors adversely affect the efficiency and feeling of comfort at work. In certain circumstances, their impact can be subjectively perceived differently. The results presented in Figure 11 show that there is very little external influence on the work of staff in both schools.

IRTIIE Vol. 4, No. 3, 2016 ISSN 1314-8788 (print), ISSN 1314-8796 (online), doi: 10.15547/artte.2016.03.009 


\section{IRTTIE}

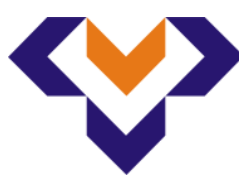

Ipplied Reseirl'ches in Technics, Technologies and Bducation

Journal of the Faculty of Technics and Technologies, Trakia University https://sites.google.com/a/trakia-uni.bg/artte/

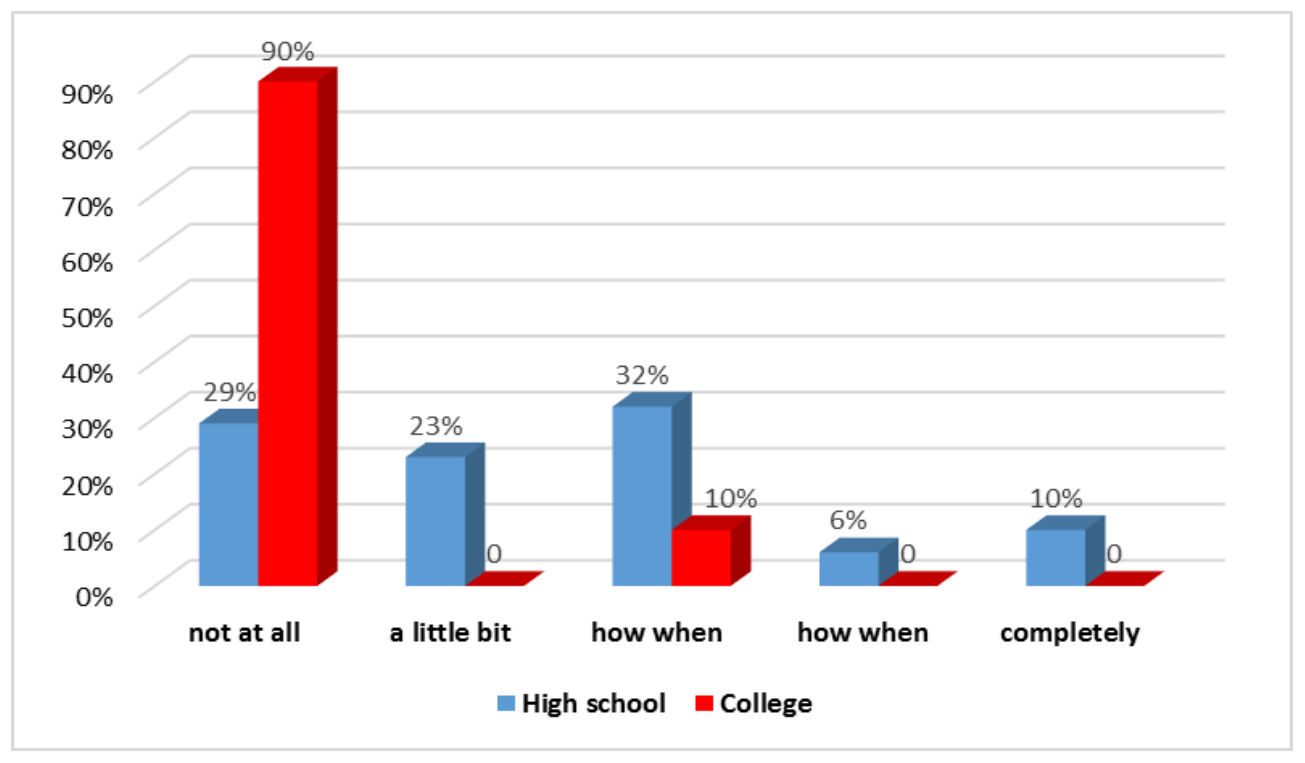

Figure 11. To what extent does your work interferes with external influences?

On the question "How often do you have a fear of losing the job?" and "How often do you think about leaving the job?" respondents from high school are almost never afraid of being redundant (36\%), but $42 \%$ of respondents think about changing a job.

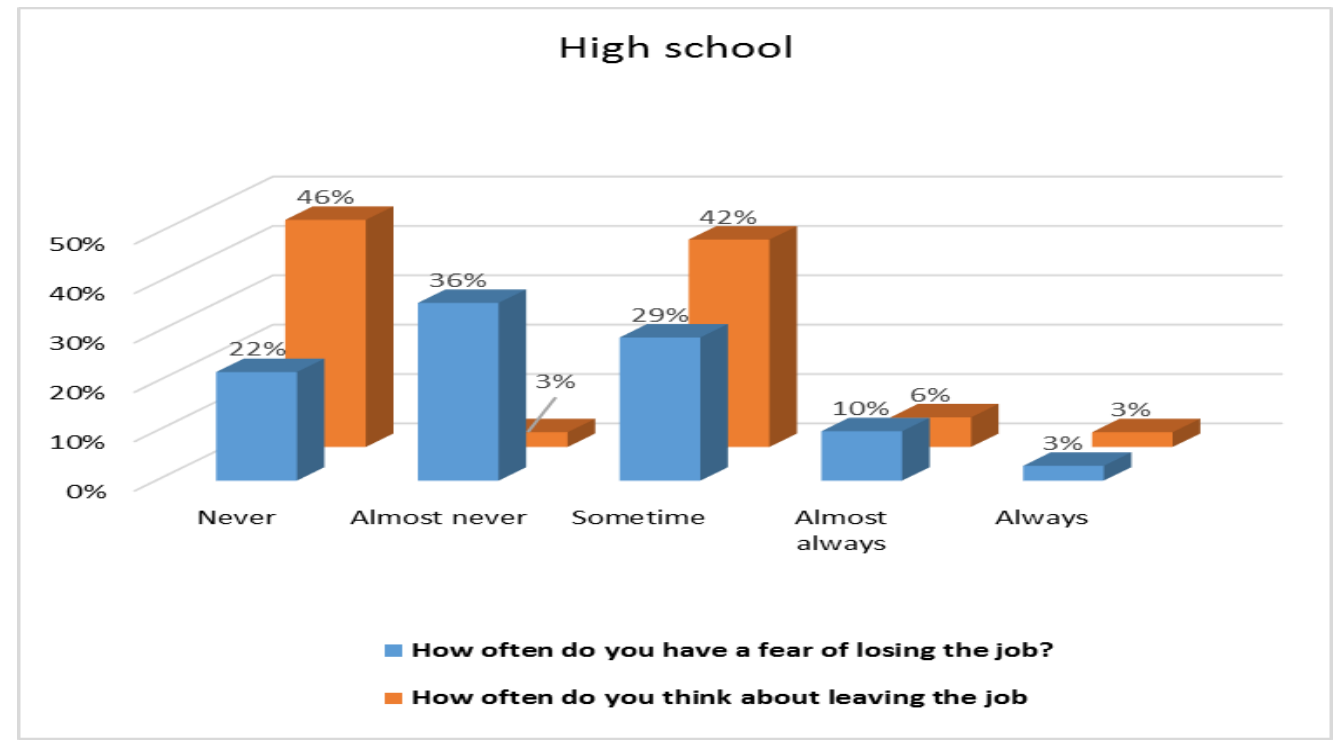

Figure 12. Answers of the respondents from high school

Respondents from college answered the same questions with: no fear of job loss (60\%), and a large number think about changing jobs as sometimes $40 \%$ and always $40 \%$, which shows the dissatisfaction of employees. 


\section{IRTITE}

Ipplied Reseirl'ches in Technics, Technologies and Bduration Journal of the Faculty of Technics and Technologies, Trakia University https://sites.google.com/a/trakia-uni.bg/artte/

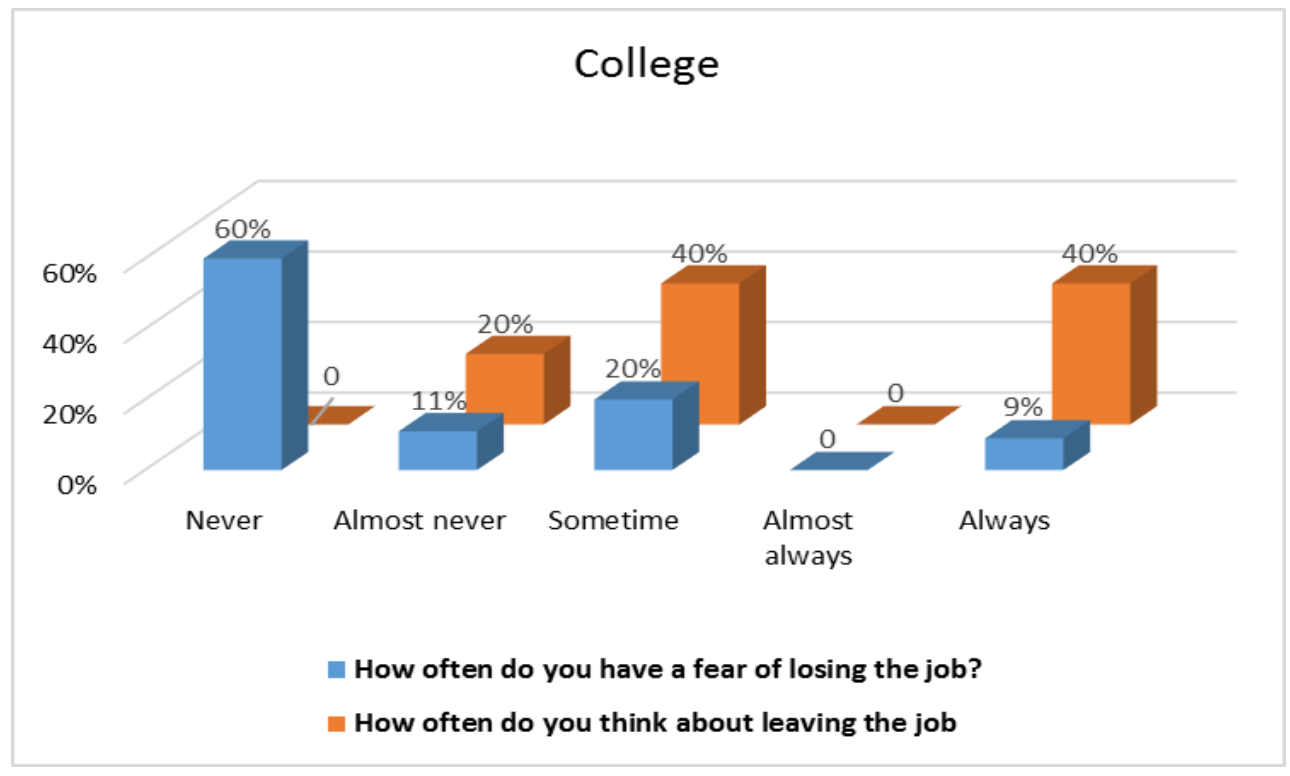

Figure 13. Answers of the respondents from college

Most people occasionally find themselves in conflict situations. Respondents in both schools often attend conflict situations, Table 3 . Due to emotional balance disorders a tired man often comes into conflict with the environment, is irritated and easily excited. Usually such conflicts result from misunderstanding, different personal beliefs and values, conflicting interests, and unmet needs or inabilities to express their own feelings and opinions.

Table 3. "How often have you attended conflict?"

\begin{tabular}{|l|c|c|c|c|c|}
\hline $\begin{array}{l}\text { How often have you } \\
\text { attended conflict? }\end{array}$ & Never & $\begin{array}{c}\text { Almost } \\
\text { never }\end{array}$ & Sometime & $\begin{array}{c}\text { Almost } \\
\text { always }\end{array}$ & Always \\
\hline high school & $10 \%$ & $10 \%$ & $74 \%$ & $6 \%$ & - \\
\hline college & - & $40 \%$ & $30 \%$ & $30 \%$ & - \\
\hline
\end{tabular}

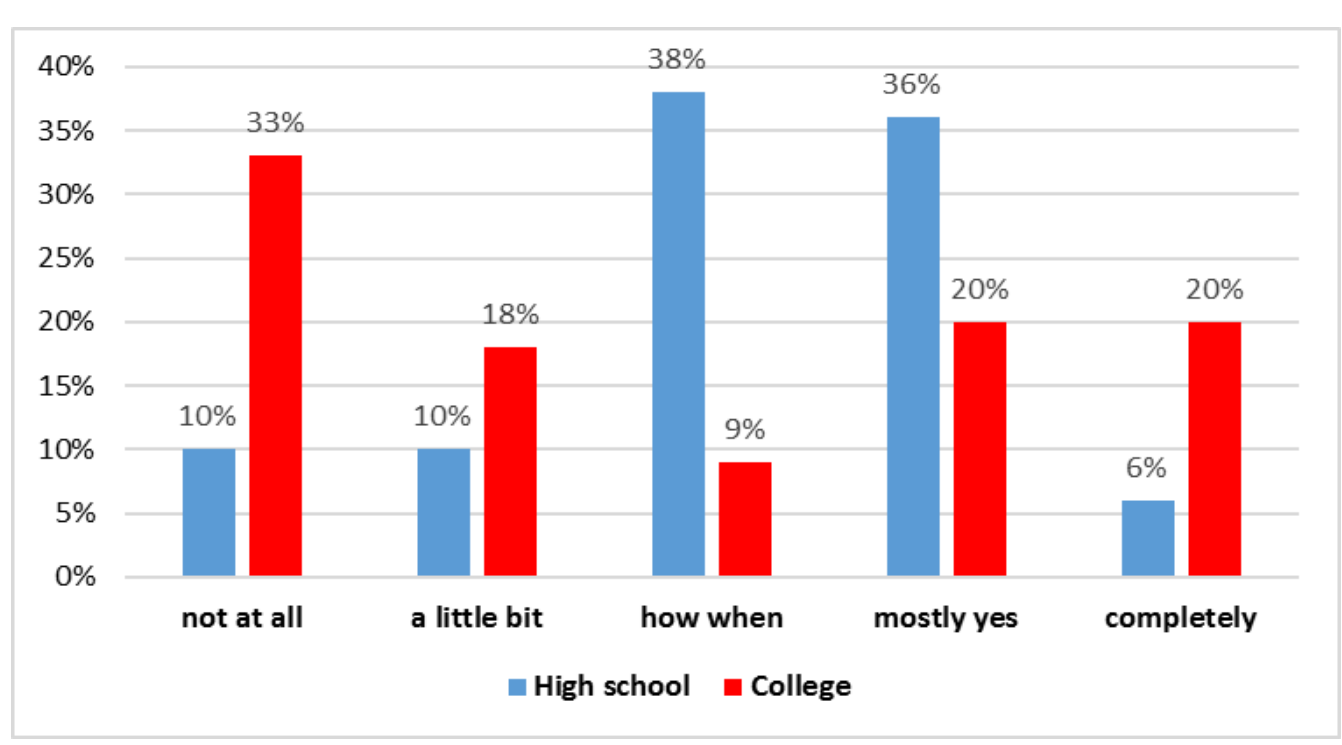

Figure 14. Impact of stress on work

IRTITE Vol. 4, No. 3, 2016 ISSN 1314-8788 (print), ISSN 1314-8796 (online), doi: 10.15547/artte.2016.03.009 


\section{ARTIIE \\ Ipplied Researreches in Technics, Technologies and Bducition \\ Journal of the Faculty of Technics and Technologies, Trakia University https:///ites.google.com/a/trakia-uni.bg/artte/}

The diagram of Figure 14 shows that $42 \%$ of respondents in high school and $40 \%$ in the college believe that stress affects their work. $33 \%$ of employees in the high school believe that stress does not directly affect the work, and about $10 \%$ in high school.

Fatigue is a phenomenon that accompanies each man's activity, reduces operating effects and negatively affect the attitude toward work. Mental fatigue occurs while performing intellectual work, while physical fatigue is the result of physical exertion. These two types of fatigue overlap just the same as physical and intellectual work. Subjective signs may not be associated with a decrease in work performance and are reflected in a decline in the criticism at work, weakening of concentration, change in behavior and mood. Objective signs of fatigue are reflected in the reduction of work performance. Reducing the quality and quantity of work performance are direct indicators of fatigue. [12]

A large number of respondents answered that they often attend conflict situations, which shows that after work they feel emotionally and physically exhausted. In high school, depending on the daily activities at work they are sometimes emotionally (52\%) and physically (48\%) exhausted, and $36 \%$ of respondents are mostly exhausted from preparing and working with students, Figure 15.

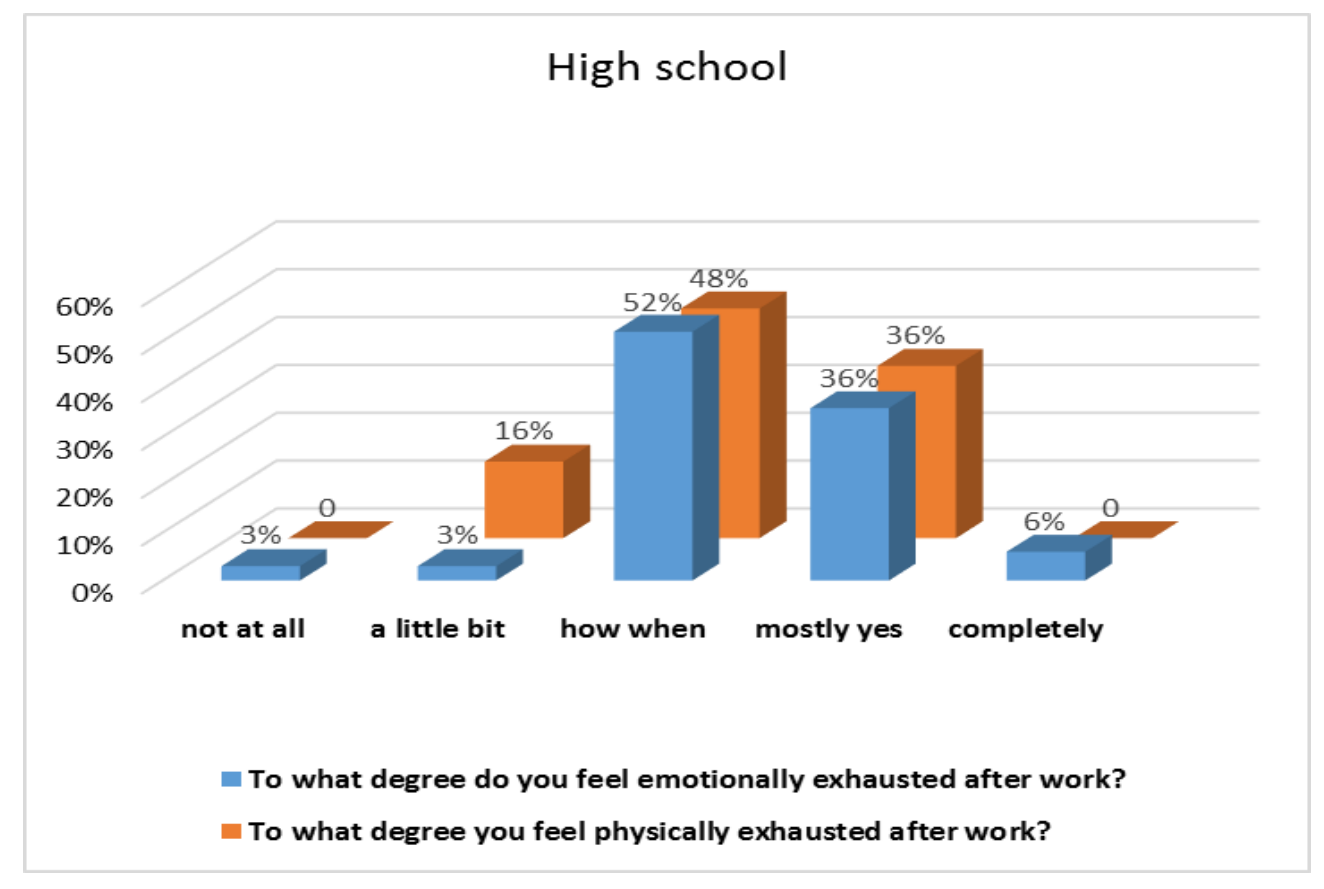

Figure 15.

Exhaustion employees after work in high school

Due to different work organization the employees in college are less physically exhausted (40\% a little bit), but they are emotionally exhausted after work (50\% of respondents), Figure 16. Exhaustion is not just a state of excessive stress, but is also a complex human reaction to a long exposure to stress. 


\section{ARTTIE $Y$}

Ipplied Researthes in Technics, Technologies and Bdurition Journal of the Faculty of Technics and Technologies, Trakia University https://sites.google.com/a/trakia-uni.bg/artte/

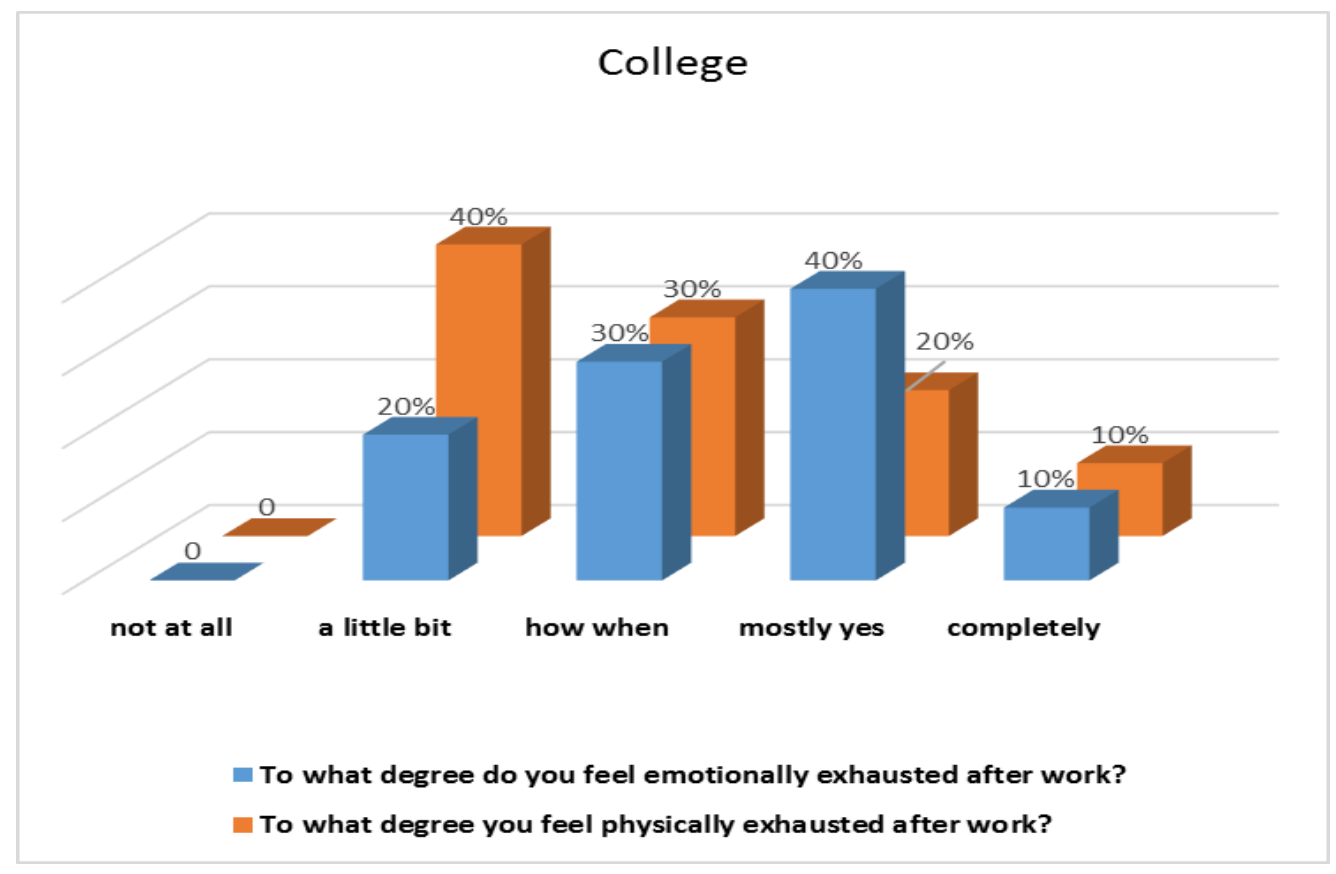

Figure 16. Exhaustion of employees in college after work

\section{CONCLUSION}

Motivation for work is a very complex concept that people have been dealing with almost since the ancient communities. Scientific approach to motivation as the phenomenon began with the Industrial Revolution in the late 18th century and experienced its peak in the late 20th century. Today this phenomenon is given great importance due to improved efficiency, effectiveness, creativity and quality of work and humanization of working conditions. When speaking of motivation we can talk about the mechanisms of satisfying basic human needs and motives in a situation of performing some work. For motivation to work the situation itself is also important, as well as the activities through which it is manifested.

Stress represents a dynamic environment in which the individual is faced with opportunities, coercion or requests whose results are uncertain but are important for him. Stress is a plot of emotional and physiological reactions that occur in response to the demands placed inside or outside the organization, and can affect both positively and negatively on the individual. The advantage is that stress encourages the employee to do his best to achieve maximum results. The negative side of stress is reflected in coercion, restrictions and requirements.

This work analyzes the impact of stress and motivation of employees in educational institutions. The survey was carried out in high school and the college. The obtained results confirmed that employees in educational institutions, especially teachers have partially different motivation factors and causes of stress at work when working both with pupils and the students. The results indicate that respondents are more influenced by intangible factors (primarily by interesting work) than by material factors, especially working conditions. As for the causes of stress at work, they are generally exhausted from working overtime and from the organizational changes in recent years in the sphere of education and therefore a large number of respondents think about changing their job, i.e.the respondents are mostly affected by the organizational causes of stress. 


\section{ARTTE $Y$}

Ipplied Resseirlohes in Technics, Technologies and Bductation Journal of the Faculty of Technics and Technologies, Trakia University https://sites.google.com/a/trakia-uni.bg/artte/

\section{REFERENCES}

[1] Siljanovski M. (2013), Značaj obrazovanja kao resursa u 21.veku, Tehnički fakultet Mihajlo Pupin, Zrenjanin.

[2] Terzić I., Stevanović D. (2013), Funkcionalni modeli finansiranja stručnog usavršavanja nastavnika u Republici Srbiji, Nacionalna konferencija sa međunarodnim učešćem RPPO13, Čačak, str. 564.

[3] Aničić O., Đekić-Lović J. (2013), Prilagođavanje učesnika obrazovnog procesa, Nacionalna konferencija sa međunarodnim učešćem "Reinženjering poslovnih procesa u obrazovanju", str. 469, Čačak.

[4] Ugrinović D., Dobrijević G., Đorđević-Boljanović J. (2015), Uticaj zadovoljstva poslom na motivaciju nastavnika srednjih škola u Srbiji, Socioeconomica, 4 (7): 197-206.

[5] Trankiem B. (2009), Stres u razredu, Zagreb, Profil, str. 231.

[6] Krnjajić S. (2003), Nastavnik pod stresom, Biblid, 35, str. 222-244.

[7] Gold Y. (1985), Does Teacher Burnout Begin with Student Teaching, Education,105(3): 254-257.

[8] Goddard R., O’Brien P., Goddard M. (2006), Work Environment Predictors of Beginning Teacher Burnout, British Educational Research Journal, 32 (6): 857- 874.

[9] Xin M., MacMillan R.B. (1999), Influences of Workplace Conditions on Teachers'Job Satisfaction, Journal of educational Research, 93 (1): 39-47.

[10] Petz B. (1985), Psihologija rada, Školska knjiga, Zagreb.

[11] Colovic G. (2012), Strategic management in the garment industry, Woodhead Publishing Limited, Cambridge, Oxford, New Delhi, Philadelphia.

[12] Colovic G. (2014), Ergonomics in the garment industry, Woodhead Publishing Limited, New Delhi. 